\title{
Understanding Alzheimer disease
}

\author{
M Vally*, F Kathrada
}

Department of Pharmacy and Pharmacology, Faculty of Health Sciences, University of the Witwatersrand, Johannesburg

*Corresponding author, email: muhammed.vally@wits.ac.za

\begin{abstract}
Alzheimer disease (AD) is a neurodegenerative disorder with an uncertain pathogenesis. It is characterised by symptoms of memory impairment, executive dysfunction and visuospatial impairment. Management goals and interventions should be based on a solid alliance with the patient and family and on thorough psychiatric, neurological and general medical evaluations of the nature and cause of cognitive deficits and associated non-cognitive symptoms. There are currently three cholinesterase inhibitors and one $\mathrm{N}$-methyl-D-aspartate (NMDA) antagonist indicated in the treatment of AD as monotherapy or in combination. Cholinesterase inhibitors remain the first-line therapy in patients with mild to moderate $A D$, which may stabilise the symptomatic cognitive and functional decline. Other pharmacotherapy options include the use of memantine which may be used by itself or in combination with cholinesterase inhibitors. These treatments are for symptomatic relief and are not disease modifying in preventing the progression of the disease
\end{abstract}

Keywords: dementia, Alzheimer disease, treatment of dementia, risk factors, management of Alzheimer disease

\section{Introduction}

Alzheimer disease (AD) is a neurodegenerative disorder with a pathogenesis and causes that are uncertain. ${ }^{1}$ It affects older adults and is the most common cause of dementia. ${ }^{1}$ AD's early clinical manifestation is selective memory impairment, but there are exceptions to this. The incidence of $A D$ increases exponentially with age over 65 years. ${ }^{2}$ AD before the age of 65 years is unusual and may be familial in nature. Familial early-onset AD accounts for approximately $1 \%$ of cases and follows a pattern of autosomal dominant inheritance. ${ }^{3,4}$ Treatment is available that may ameliorate some of the symptoms but currently there is no cure or disease-modifying therapy available and the disease will inevitably progress. ${ }^{1}$

\section{Pathophysiology}

As discussed above, the pathogenesis of $A D$ is uncertain. ${ }^{1}$ Some of the early neuropathological changes in $A D$ include the following ${ }^{5-8}$ :

1. Neuritic plaques, which are associated with neuronal injury and may be characterised by amyloid which is formed from amyloid beta plus dystrophic neurites which frequently has phospho-tau immunoreactivity.

2. Extracellular deposits of amyloid beta peptides.

3. Neurofibrillary degeneration which is best illustrated by neurofibrillary tangles.

Table I describes other pathological changes commonly observed in association with AD. ${ }^{9-16}$ The pathogenesis of all forms of $A D$ seems to share the commonality of an overproduction and/or a decreased clearance of amyloid beta peptides. ${ }^{17}$ These peptides are produced by cleavage of mature protein translated from the amyloid precusor protein (APP) gene and cleaved by beta-secretase and gamma-secretase. Presenillin forms part of the gamma-secretase complex and mutations of the presenilin 1 (PSEN 1) or presenilin 2 (PSEN 2) genes tend to favour the production of amyloid beta. Amyloid beta or the forms that are produced through mutations of PSEN 1 or PSEN 2 are neurotoxic. ${ }^{17}$

A second protein involved in the pathogenesis of AD is tau. ${ }^{18}$ $20 \mathrm{Tau}$ is a microtubule-associated protein which aids in microtubule assembly and stabilisation. In $A D$, these proteins become hyperphosphorylated and aggregate to form paired

Table I. Several other pathological changes found with $A D^{9-14}$

In addition to the essential features discussed above, several other pathological features are observed in patients with AD. These include:

1. Cerebral amyloid angiopathy is often found in patients with parenchymal amyloid beta deposits ${ }^{9,10}$

2. Inclusions of abnormal alpha-synucle in accumulation called Lewy bodies, are common in the setting of intermediate-to-high levels of AD neuropathologic change. ${ }^{11,12}$ Lewy bodies may also be found in some cases of early-onset familial AD. ${ }^{13,14}$

3. Pathological changes of vascular brain injury are caused by oligaemia, hypoxaemia, or ischaemia involving different calibre vessels in different regions of the brain.

4. Hippocampal sclerosis (HS), defined by pyramidal cell loss and gliosis in the hippocampal formation that is out of proportion to AD neuropathological change, can be observed alone or in the context of $A D$, frontotemporal lobar degeneration, or vascular brain injury. ${ }^{15}$

5. Immunoreactive inclusions of transactive response DNA binding protein $43 \mathrm{kD}$ (TDP-43) are also commonly observed in cases with $A D$ neuropathological change ${ }^{16}$ 
helical filament (PHF) tau. These are a major component of neurofibrillary tangles within the neuronal cytoplasm. Experimental models have suggested that the accumulations of these altered proteins are neurotoxic. Additionally, pathological forms of tau between neurons have been proposed as a mechanism by which AD spreads in the brain. ${ }^{18-20}$ Various other genes and proteins have been implicated in the pathogenesis of $A D$ but that is beyond the scope of this review.

\section{Risk factors for developing Alzheimer's disease}

Aside from genetics as a risk factor for $A D$, a variety of different factors may influence a patient's risk for developing AD. ${ }^{21}$ Risk factors for vascular disease such as hypertension, diabetes and obesity may increase the risk of developing $A D$, particularly if these diseases are present in midlife. ${ }^{21}$ The exact pathogenesis of linking these cardiometabolic risk factors to $A D$ is poorly understood and an area of active research. ${ }^{22-31}$ Brain cholesterol metabolism may also be an important risk factor for AD. . $^{32-36}$ The relationship between $A D$ and blood lipoproteins (such as LDL-C) is complex and inconsistent. ${ }^{32-36}$ It is clear, however, that cerebrovascular disease and $A D$ do frequently co-exist. ${ }^{37}$ One must also be aware that hypertension is a risk factor for cerebrovascular disease. ${ }^{21,38-40}$ Cerebrovascular disease is associated with worse cognitive performance in patients with $A D$ and studies have suggested that cerebrovascular disease lowers the threshold for clinical dementia in patients with a diagnosis of AD. ${ }^{41-46}$

\section{Clinical features}

Some of the cardinal symptoms of $A D$ include memory impairment, executive dysfunction and visuospatial impairment. ${ }^{47,48}$ The last two symptoms tend to present relatively early, while language and behavioural symptoms tend to manifest later in the course of the disease. Less common symptoms include language deficits and visuospatial abnormalities. ${ }^{47,48}$ Table II describes the signs and symptoms of $A D$ with their relevant description. ${ }^{49-73}$

Table II. Signs and symptoms of AD with a clinical description ${ }^{49-73}$

\begin{tabular}{|c|c|}
\hline Symptom & Clinical description \\
\hline \multicolumn{2}{|r|}{ Cardinal Signs and Symptoms } \\
\hline Memory impairment & $\begin{array}{l}\text { 1. Pattern in } \mathrm{AD} \text { is distinctive. }{ }^{49} \\
\text { 2. Memory of events occurring at a particular time and place (declarative memory) is profoundly affected. }{ }^{49} \\
\text { 3. Procedural memory and motor learning is spared until quite late into disease progression. }{ }^{49} \\
\text { 4. Memory of recent events is significantly impaired in early AD. } .^{50-52} \\
\text { 5. Immediate memory (e.g. mental rehearsal of a phone number) is spared early in disease progression. } .^{50-52} \\
\text { 6. Consolidated long-term memory tends to be spared early in the course of the disease. }{ }^{50-52} \\
\text { 7. Deficits develop insidiously and progress slowly over time. } .^{50-52}\end{array}$ \\
\hline $\begin{array}{l}\text { Executive function and } \\
\text { judgement }\end{array}$ & $\begin{array}{l}\text { 1. In the early stages, this may range from subtle to prominent impairment. }{ }^{53} \\
\text { 2. Family members or co-workers may notice that the AD patient is less organised or less motivated. }{ }^{53} \\
\text { 3. Multitasking is often compromised significantly. } \\
\text { 4. Patient has poor insight and reduced ability for abstract reasoning. }{ }^{54,55} \\
\text { 5. As AD progresses, patient may develop an inability to complete tasks. } .^{54,55} \\
\text { 6. Anosognosia (reduced insight into deficits) is a feature of AD. }{ }^{54,55} \\
\text { 7. Patients with AD may often underestimate their deficits or provide alibis or explanations for when the } \\
\text { deficit is pointed out. }{ }^{54,55} \\
\text { 8. Loss of insight increases overtime with disease severity. }{ }^{56} \\
\text { 9. Loss of insight may be associated with behavioural disturbances. }{ }^{57,58} \\
\text { 10. Patients with preserved insight tend to develop depression. }{ }^{57,58} \\
\text { 11. Patients with lack of sight develop agitation, disinhibition and even psychotic features. }{ }^{57,58}\end{array}$ \\
\hline $\begin{array}{l}\text { Behavioural and psychological } \\
\text { symptoms }\end{array}$ & $\begin{array}{l}\text { 1. Neuropsychiatric symptoms are in patients with } A D \cdot 57,58 \\
\text { 2. Neuropsychiatric symptoms tend to occur in the mid to late stage of AD. } 57,58 \\
\text { 3. Apathy may occur in these patients and may be clinically indistinguishable from depression. }{ }^{57,58}\end{array}$ \\
\hline
\end{tabular}

\section{Other Signs and Symptoms}

\begin{tabular}{|c|c|}
\hline Apraxia & $\begin{array}{l}\text { 1. Occurs later in the disease after deficits in memory and language become apparent. }{ }^{59} \\
\text { 2. Dyspraxia can be elicited by asking the patient to perform ideomotor tasks e.g. combing of hair. }{ }^{60,61} \\
\text { 3. Dyspraxia leads to progressive difficulty with complex, multistep motor activities and later with dressing, } \\
\text { eating and other self-care tasks. }{ }^{.2}\end{array}$ \\
\hline Olfactory dysfunction & $\begin{array}{l}\text { 1. Changes in olfactory function are common in patients with AD. }{ }^{63,64} \\
\text { 2. Olfactory dysfunction is not a clinical symptom reported by patients or their families. }{ }^{65}\end{array}$ \\
\hline Sleep disturbances & $\begin{array}{l}\text { 1. These are common in patients with } A D .^{66} \\
\text { 2. AD patients tend to spend more time in the bed awake and have more fragmented sleeping patterns when } \\
\text { compared to older adults without AD. }{ }^{66}\end{array}$ \\
\hline Seizures & $\begin{array}{l}\text { 1. Usually occurs in the later stages of AD. }{ }^{67-69} \\
\text { 2. Younger patients with autosomal dominant forms of AD have a higher risk of seizures earlier in the course } \\
\text { of the disease. }{ }^{70,71} \\
\text { 3. Predominant seizure type is focal nonmotor with impaired awareness and symptoms suggest temporal } \\
\text { lobe onset i.e. amnestic spells, unexplained emotions, metallic taste, rising epigastric sensation. }{ }^{71}\end{array}$ \\
\hline Motor signs & $\begin{array}{l}\text { 1. Extrapyramidal motor signs and myoclonus may occur at later stages of } A D .^{72,73} \\
\text { 2. If motor symptoms occur at earlier stages of } A D \text { other diagnoses should be considered. } .^{72,73} \\
\text { 3. Emergence of behavioural disturbances include agitation, aggression, wandering and psychosis } \\
\text { (hallucinations, delusions, misidentification syndromes) may be problematic in patient management. }{ }^{72,73}\end{array}$ \\
\hline
\end{tabular}


Table III. The NIA-AA clinical assessment characteristics in confirming diagnosis of $A D^{73}$

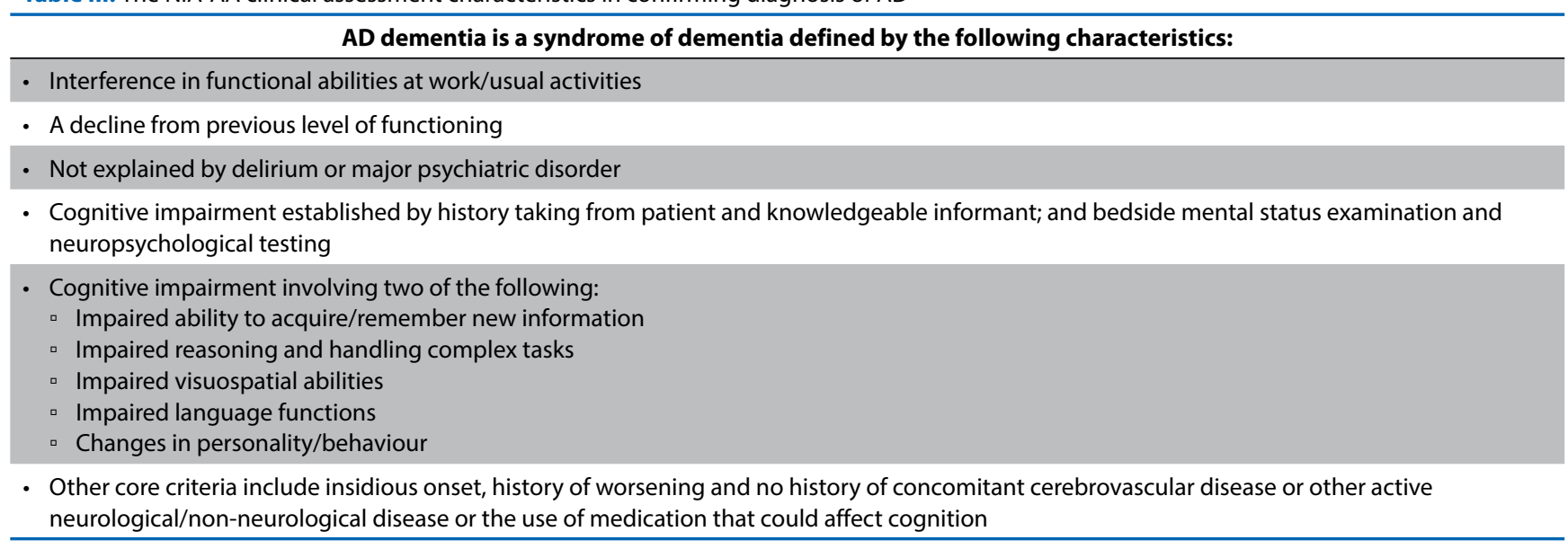

\section{Diagnosis}

Alzheimer's disease is diagnosed based on clinical assessment and neuroimaging studies and is suspected in any older adult with insidious onset, a progressive decline in memory and in at least one other cognitive domain. ${ }^{47,73}$ The two commonest used criteria in the diagnosis of $A D$ include the clinical criteria established by the National Institute on Aging and the Alzheimer's Association (NIA-AA) and the Diagnostic and Statistical Manual of Mental Disorders (DSM). ${ }^{73,48}$ Table III outlines the criteria in diagnosis of $A D$ as established by the NIA-AA. ${ }^{73}$

The DSM clinical criteria for AD has been expanded beyond the previous five domains (memory, aphasia, apraxia, agnosia, and executive function) to include learning, language, complex attention, perceptual motor and social cognition. ${ }^{48}$ While less validated when compared to the NIA-AA, the DSM criteria appear to have similar accuracy. ${ }^{74,75}$

The NIA-AA recent diagnostic guidelines have defined three stages of $A D^{76}$ :

- Preclinical phase: neuropathological changes occur, no overt (or only subtle) symptoms

- Phase of mild cognitive impairment: symptoms become apparent; ADLs are preserved; patient does not have dementia

- Dementia phase: ADLs are impaired

There may be preclinical neurologic changes in the form of cerebrospinal fluid or amyloid imaging biomarkers. ${ }^{76}$ However, AD diagnosis is principally based on clinical criteria (Table III). ${ }^{73}$

\section{Differential diagnosis}

The most common disorders considered in the differential diagnosis of $A D$ are vascular dementia and neurodegenerative dementias. The most common neurodegenerative dementias after $A D$ include dementia with Lewy bodies (DLB) and frontotemporal dementia (FTD). ${ }^{77,78}$

\section{Pharmacological therapy}

Management goals and interventions should be based on a solid alliance with the patient and family as well as thorough psychiatric, neurological and general medical evaluations of the nature and cause of cognitive deficits and associated noncognitive symptoms. There are currently three cholinesterase inhibitors and one N-methyl-D-aspartate (NMDA) antagonist indicated in the treatment of $A D$ as monotherapy or in combination. ${ }^{79}$

\section{Pharmacological therapy: Memantine}

Memantine is a NMDA receptor antagonist which is proposed to be neuroprotective by preventing glutamatergic excitotoxicity in blocking excessive stimulation of NMDA receptors. ${ }^{80}$ This action protects the neurons from further damage and restores the physiological function of remaining neurons resulting in symptomatic improvement. ${ }^{81}$ Glutamate stimulation of NMDA receptors has been implicated in memory processes and dementia. ${ }^{82}$ Memantine appears to have modest benefits in patients with moderate to severe $A D$ based on a 28-week randomised trial of 252 patients. ${ }^{82}$ This study found that memantine reduced deterioration on multiple scales of clinical efficacy (Table V).82 Memantine appears to have fewer sideeffects than the cholinergic agents, with dizziness being the most common adverse effect. ${ }^{82}$ However, there is a lack of evidence that patients with milder AD benefit from memantine, with no effect on behaviour or ADLs. ${ }^{82}$ Memantine may be introduced in moderate to severe disease stages and can be used as monotherapy or in combination with a cholinesterase inhibitor. ${ }^{83}$

\section{Pharmacological therapy: Cholinesterase inhibitors}

Patients with $A D$ have reduced cerebral content of choline acetyl transferase, which leads to a decrease in acetylcholine synthesis and impaired cholinergic function. Cholinesterase inhibitors used in the treatment of $A D$ increase cholinergic transmission by inhibiting cholinesterase at the synaptic cleft and provide modest benefit in patients with dementia. Unlike memantine, cholinesterase inhibitors are considered symptomatic therapies which are not neuroprotective. ${ }^{83}$ To date, three cholinesterase inhibitors are indicated in mild to moderate AD; donepezil, galantamine and rivastigmine, while donepezil is also indicated in moderate to severe AD (Table IV). ${ }^{83}$ High dose rivastigmine patch is approved for mild to moderate and severe AD based on the positive findings of recent studies. ${ }^{83,84,85}$ The cholinesterase inhibitors have demonstrated clinical benefits on cognitive 
function, global clinical status, and performance of ADLs (Table V). ${ }^{86-93}$ There are no clinically meaningful differences between the efficacy of the individual agents. ${ }^{83}$ Efficacy and tolerability of cholinesterase inhibitors are dose-dependant, so while high doses may be efficacious, adverse events can be doselimiting. ${ }^{83-85}$ The agents have similar tolerability profiles, with nausea, vomiting and diarrhoea being the most common adverse effects. ${ }^{94}$ Patients with bradycardias or bradyarrhythmia's should be carefully monitored if treated with cholinesterase inhibitors, as they have an increased risk of syncope or dizziness. ${ }^{76}$ Treatment is individualised; patients can be switched from one cholinesterase inhibitor to another if the initial agent is poorly tolerated or ineffective. ${ }^{83}$ Systematic reviews and meta-analyses of cholinesterase inhibitors illustrate that they delay the decline in cognitive function as measured by the AD Assessment Scale cognitive subscale (ADAS-cog), global clinical rating, behaviour and ADLs over 6-12-month periods. These benefits seem to be applicable to mild, moderate and severe AD. ${ }^{95}$ Pivotal six month placebo-controlled studies further highlight the beneficial effects of cholinesterase inhibitors in patients with mild to moderate $A D$, on cognitive and global functioning (Table V). ${ }^{86-}$ ${ }^{93}$ Extended 6-12 month trials provide evidence that patients receiving cholinesterase inhibitors can be maintained near pretreatment baseline levels for at least 12 months of therapy and then decline, but appear to maintain higher levels of function than expected if untreated. ${ }^{96}$

\section{Pharmacological therapy: Combination therapy}

The combination therapy of memantine with a cholinesterase inhibitor, which affect separate neurotransmitter systems in $A D$, is useful in patients with advanced disease conferring independent clinical benefits. The combination leads to modest improvements in cognition and global outcomes in patients with advanced disease. ${ }^{97}$ A study in which patients treated with memantine plus donepezil resulted in significantly better outcomes than placebo plus donepezil on measures of cognition, ADLs, global outcome and behaviour (Table V). ${ }^{98}$ These results together with previous studies, suggest that combination therapy of memantine with a cholinesterase inhibitor represents a new approach for the treatment of patients with moderate to severe $A D$ which may improve efficacy relative to single-agent therapy and may ameliorate gastrointestinal adverse effects of cholinesterase inhibitors. ${ }^{83}$

Table IV. Approved AD therapies ${ }^{83}$

\begin{tabular}{|c|c|c|}
\hline AD stage & Class & Agent \\
\hline Mild to moderate & $\begin{array}{l}\text { Cholinesterase } \\
\text { inhibitor }\end{array}$ & $\begin{array}{l}\text { Donepezil (5-10 mg) } \\
\text { Rivastigmine }(6-12 \mathrm{mg}) \\
\text { Galantamine }(8-24 \mathrm{mg})\end{array}$ \\
\hline $\begin{array}{l}\text { Moderate to } \\
\text { severe }\end{array}$ & $\begin{array}{l}\text { Cholinesterase } \\
\text { inhibitor } \\
\text { NMDA antagonist }\end{array}$ & $\begin{array}{l}\text { Donepezil/Rivastigmine } \\
\text { plus } \\
\text { Memantine }(10-20 \mathrm{mg}) \\
\text { OR } \\
\text { Memantine alone }\end{array}$ \\
\hline
\end{tabular}

Table V. Evidence relating to pharmacotherapy of cholinesterase inhibitors and NMDA antagonists in improving symptoms of $A D^{82,86-93,98-100}$

\begin{tabular}{|c|c|c|c|c|c|c|}
\hline Reference & Agent & $\begin{array}{l}\text { Dose studied } \\
\quad(\mathrm{mg} / \mathrm{d})\end{array}$ & $\mathbf{N}$ & $\begin{array}{l}\text { Duration } \\
\text { (wk) }\end{array}$ & $\begin{array}{c}\text { Positive Outcome } \\
\text { Measure }\end{array}$ & Comments \\
\hline \multicolumn{7}{|c|}{ Early Alzheimer's disease } \\
\hline Seltzer et al, $2004^{99}$ & Donepezil & $5-10$ & 153 & 24 & ADCS-cog & ADAS-cog: $\geq 4$-point change $(P \leq 0.001)$ \\
\hline \multicolumn{7}{|c|}{ Mild to moderate Alzheimer's disease } \\
\hline Rogers et al, $1998^{86}$ & Donepezil & $5-10$ & 468 & 15 & $\begin{array}{l}\text { ADAS-cog, MMSE } \\
\text { CIBIC-Plus }\end{array}$ & $\begin{array}{l}\text { ADAS-cog: } \geq 4 \text {-point change }(P=0.008) \\
\text { CIBIC-Plus: } \leq 3 \text {-point change }(P<0.001)\end{array}$ \\
\hline Rogers et al, $1998^{87}$ & Donepezil & $5-10$ & 473 & 24 & $\begin{array}{l}\text { ADAS-cog, MMSE } \\
\text { (CIBIC-Plus) }\end{array}$ & $\begin{array}{l}\text { ADAS-cog: } \geq 4 \text {-point change }(P=0.008) \\
\text { CIBIC-Plus: } \leq 3 \text {-point change }(P<0.001)\end{array}$ \\
\hline Burns et al, $1999^{88}$ & Donepezil & $5-10$ & 818 & 30 & $\begin{array}{l}\text { ADAS-cog, CIBIC-Plus } \\
\text { (CDR-SB) }\end{array}$ & CIBIC-Plus: $\leq 3$-point change $(P<0.05)$ \\
\hline $\begin{array}{l}\text { Farlow et al, } \\
2013^{89,90}\end{array}$ & Rivastigmine & $1-4,6-12$ & 545 & 26 & ADAS-cog, CIBIC-Plus & ADAS-cog: $\geq 4$-point change $(P<0.001)$ \\
\hline Rosler et al, 199991 & Rivastigmine & $1-4,6-12$ & 725 & 26 & $\begin{array}{l}\text { ADAS-cog, CIBIC-Plus, } \\
\text { PDS }\end{array}$ & $\begin{array}{l}\text { ADAS-cog: } \geq 4 \text {-point change }(P<0.05) \\
\text { CIBIC-Plus: } 2 \text {-point change }(P<0.001)\end{array}$ \\
\hline $\begin{array}{l}\text { Wilcock et al, } \\
2000^{92}\end{array}$ & Galantamine & 24,32 & 653 & 26 & $\begin{array}{l}\text { ADAS-cog, CIBIC-Plus, } \\
\text { DAD }\end{array}$ & $\begin{array}{l}\text { ADAS-cog: } \geq 4 \text {-point change }(P<0.001) \\
\text { CIBIC-Plus: } 2 \text {-point change }(P<0.05)\end{array}$ \\
\hline Tariot et al, $2000^{93}$ & Galantamine & $18,16,24$ & 978 & 21 & $\begin{array}{l}\text { ADAS-cog, CIBIC-Plus } \\
\text { (ADAS-ADL, NPI) }\end{array}$ & ADAS-cog: $\geq 7$-point change $(P<0.001)$ \\
\hline \multicolumn{7}{|l|}{ Moderate to Severe } \\
\hline $\begin{array}{l}\text { Feldman et al, } \\
2001^{100}\end{array}$ & Donepezil & $5-10$ & 290 & 24 & $\begin{array}{l}\text { CIBIC-Plus } \\
\text { (MMSE, SIB, DAD, FRS, } \\
\text { NPI) }\end{array}$ & CIBIC-Plus: $\leq 3$-point change $(\mathrm{P}<0.001)$ \\
\hline $\begin{array}{l}\text { Reisberg et al, } \\
2003^{82}\end{array}$ & Memantine & 20 & 252 & 28 & $\begin{array}{l}\text { CIBIC-Plus, } \\
\text { ADCS-ADLsev (SIB) }\end{array}$ & $\begin{array}{l}\text { CIBIC-Plus: } \leq 3 \text {-point change }(P=0.03 \text {, } \\
95 \% \text { Cl:-0.51-0.02) }\end{array}$ \\
\hline Tariot et al, $2004^{98}$ & $\begin{array}{l}\text { Memantine (added } \\
\text { to stable donepezil } \\
\text { regimen) }\end{array}$ & 20 & 404 & 24 & $\begin{array}{l}\text { SIB, ADCS-ADL19 } \\
\text { (CIBIC-Plus, NPI, BCG) }\end{array}$ & $\begin{array}{l}\text { SIB: } 0.9(0.67) \text { vs }-2.5(0.69)(P<0.001) \\
\text { ADCS-ADL 19: } \geq 2 \text { point change }(P=0.02) \\
\text { CIBIC-Plus: } 2 \text {-point change }(P=0.03)\end{array}$ \\
\hline
\end{tabular}

ADCS-cog: Alzheimer's Disease Assessment Scale-cognitive subscale, CIBIC-Plus: Clinicians Interview Based Impression of Change plus Caregivers Input, CDR-SB: Clinical dementia rating-sum of boxes, PDS: Progressive Deterioration Scale, GBS: Gottfries-Brane-Steen, ADCS-ADLsev: Alzheimer's Disease Cooperative study Activities of Daily Living Inventory modified for severe dementia , ADCS-ADL19: Alzheimer's Disease Cooperative study Activities of Daily Living Inventory, MMSE: Mini Mental Status Examination, SIB: Severe Impairment Battery, a measure of cognition, DAD = Disability Assessment for Dementia, NPI: Neuropsychiatric Inventory, BGP: Behaviour Rating Scale for geriatric patients 


\section{Nonpharmacological therapy}

Behavioural disturbances can profoundly affect patients with dementia as well as their families and caregivers. Recognition and treatment of behavioural symptoms and mood disorders are important aspects of the care of patients with dementia. ${ }^{83}$ Table VI describes the nonpharmacological approaches to manage common behavioural symptoms.

Table VI. Nonpharmacological approaches to manage behavioural symptoms and mood disorders in patients with $A D^{83}$

\begin{tabular}{ll}
\hline Behavioural symptom & \multicolumn{1}{c}{ Nonpharmacological intervention } \\
\hline Apathy & $\begin{array}{l}\text { Stimulation activities } \\
\text { Simple tasks }\end{array}$ \\
\hline Sleep disturbances & $\begin{array}{l}\text { Take steps to maintain regular, good quality } \\
\text { sleep } \\
\text { Stimulation during the day } \\
\text { Reduction in excessive noise/stimulation } \\
\text { in evening }\end{array}$ \\
\hline Irritability/agitation & $\begin{array}{l}\text { Break down tasks into simple steps } \\
\text { Redirection }\end{array}$ \\
\hline Wandering & $\begin{array}{l}\text { Visual cues } \\
\text { Exercise } \\
\text { Safe places to wander }\end{array}$ \\
\hline Mood disorders & Exercise \\
\hline Psychotic disorder & $\begin{array}{l}\text { Reassurance } \\
\text { Distraction rather than confrontation } \\
\text { Removal of potential sources of confusion } \\
\text { disorders }\end{array}$ \\
\hline
\end{tabular}

Inadequate nutrition is common in patients with $A D$ and is associated with increased morbidity and mortality. ${ }^{101}$ Interventions such as oral nutritional supplements may improve weight and fat-free mass. ${ }^{102}$ Nonpharmacological aims in helping cognitive function in $A D$ involves cognitive rehabilitation. This involves cognitive stimulation programmes to maintain memory and higher cognitive function. ${ }^{103}$ In terms of improving physical functioning, studies have demonstrated that formal exercise programmes may improve physical functioning or at least slow the progression of functional decline in patients with AD. ${ }^{103-105}$ However, exercise programmes do not appear to improve any cognitive functioning in adults with $A D \cdot{ }^{104-107}$ In addition to exercise, individualised occupational therapy sessions focused on training patients and caregivers in the use of aids, coping behaviours, and strategies to compensate for functional deficits, demonstrated improvements in motor and process skills in daily activities. ${ }^{108}$ These multidisciplinary, nonpharmacological approaches to management of dementia have significant advantages in having none of the side-effects that significantly complicate drug treatment in patients with $A D$.

\section{Conclusion}

The benefits of early investigating and diagnosis of AD include instigation of pharmacological symptomatic treatments and the initiation of psychosocial support processes. Cholinesterase inhibitors remain the first-line therapy in patients with mild to moderate $A D$, which may stabilise symptomatic cognitive and functional decline. Memantine, a glutamatergic partial antagonist, has shown to be beneficial in the treatment of moderate to severe cases of $A D$ either alone or in combination with a cholinesterase inhibitor. However, these treatments are for symptomatic relief and are not disease modifying in preventing the progression of the disease.

\section{References}

1. Ballard C, Gauthier S, Corbett A, et al. Alzheimer's disease. Lancet 2011;377:1019.

2. Braak $H$, Braak E. Frequency of stages of Alzheimer-related lesions in different age categories. Neurobiol Aging 1997;18:351.

3. Ryman DC, Acosta-Baena N, Aisen PS, et al. Symptom onset in autosomal dominant Alzheimer disease: a systematic review and meta-analysis. Neurology 2014;83:253.

4. Schupf N, Kapell D, Nightingale B, et al. Earlier onset of Alzheimer's disease in men with Down syndrome. Neurology 1998;50:991.

5. Masliah E, Terry RD, Mallory M, et al. Diffuse plaques do not accentuate synapse loss in Alzheimer's disease. Am J Pathol 1990;137:1293.

6. Masliah E, Mallory M, Deerinck $T$, et al. Re-evaluation of the structural organization of neuritic plaques in Alzheimer's disease. J Neuropathol Exp Neurol 1993;52:619.

7. Terry RD, Masliah E, Salmon DP, et al. Physical basis of cognitive alterations in Alzheimer's disease: synapse loss is the major correlate of cognitive impairment Ann Neurol 1991;30:572.

8. DeKosky ST, Scheff SW. Synapse loss in frontal cortex biopsies in Alzheimer's disease: correlation with cognitive severity. Ann Neurol 1990;27:457.

9. Vonsattel JP, Myers RH, Hedley-Whyte ET, et al. Cerebral amyloid angiopathy without and with cerebral hemorrhages: a comparative histological study. Ann Neurol 1991;30:637.

10. Thal DR, Griffin WS, de Vos RA, Ghebremedhin E. Cerebral amyloid angiopathy and its relationship to Alzheimer's disease. Acta Neuropathol 2008;115:599.

11. Hamilton RL. Lewy bodies in Alzheimer's disease: a neuropathological review of 145 cases using alpha-synuclein immunohistochemistry. Brain Pathol 2000;10:378.

12. Uchikado H, Lin WL, DeLucia MW, Dickson DW. Alzheimer disease with amygdala Lewy bodies: a distinct form of alpha-synucleinopathy. J Neuropathol Exp Neurol 2006;65:685

13. Lippa CF, Duda JE, Grossman M, et al. DLB and PDD boundary issues: diagnosis, treatment, molecular pathology, and biomarkers. Neurology 2007;68:812.

14. Leverenz JB, Fishel MA, Peskind ER, et al. Lewy body pathology in familial Alzheimer disease: evidence for disease- and mutation-specific pathologic phenotype. Arch Neurol 2006;63:370.

15. Amador-Ortiz C, Dickson DW. Neuropathology of hippocampal sclerosis. Handb Clin Neurol 2008;89:569.

16. James BD, Wilson RS, Boyle PA, et al. TDP-43 stage, mixed pathologies, and clinical Alzheimer'stype dementia. Brain 2016.

17. Gremer $L$, Schölzel $D$, Schenk $C$, et al. Fibril structure of amyloid- $\beta(1-42)$ by cryo-electron microscopy. Science 2017;358:116.

18. Guo JL, Lee VM. Seeding of normal Tau by pathological Tau conformers drives pathogenesis of Alzheimer-like tangles. J Biol Chem 2011;286:15317.

19. Iba M, Guo JL, McBride JD, et al. Synthetic tau fibrils mediate transmission of neurofibrillary tangles in a transgenic mouse model of Alzheimer's-like tauopathy. J Neurosci 2013;33:1024.

20. Medina $M$, Avila J. The role of extracellular Tau in the spreading of neurofibrillary pathology. Front Cell Neurosci 2014;8:113.

21. Gottesman RF, Albert MS, Alonso A, et al. Associations between midlife vascular risk factors and 25-year incident dementia in the atherosclerosis risk in communities (ARIC) Cohort. JAMA Neurol 2017;74:1246.

22. Biessels GJ, Staekenborg S, Brunner E, et al. Risk of dementia in diabetes mellitus: a systematic review. Lancet Neurol 2006;5:64.

23. Peila R, Rodriguez BL, White LR, Launer LJ. Fasting insulin and incident dementia in an elderly population of Japanese-American men. Neurology 2004;63:228.

24. Craft S, Watson GS. Insulin and neurodegenerative disease: shared and specific mechanisms. Lancet Neurol 2004;3:169.

25. Geroldi C, Frisoni GB, Paolisso G, et al. Insulin resistance in cognitive impairment: the InCHIANTI study. Arch Neurol 2005;62:1067. 
26. Fishel MA, Watson GS, Montine TJ, et al. Hyperinsulinemia provokes synchronous increases in central inflammation and beta-amyloid in normal adults. Arch Neurol 2005;62:1539.

27. Kulstad JJ, Green PS, Cook DG, et al. Differential modulation of plasma beta-amyloid by insulin in patients with Alzheimer disease. Neurology 2006;66:1506.

28. Rönnemaa E, Zethelius $B$, Sundelöf J, et al. Impaired insulin secretion increases the risk of Alzheimer disease. Neurology 2008;71:1065.

29. Matsuzaki T, Sasaki K, Tanizaki Y, et al. Insulin resistance is associated with the pathology of Alzheimer disease: the Hisayama study. Neurology 2010;75:764.

30. Schrijvers EM, Witteman JC, Sijbrands EJ, et al. Insulin metabolism and the risk of Alzheimer disease: the Rotterdam Study. Neurology 2010;75:1982.

31. Burns JM, Donnelly JE, Anderson HS, et al. Peripheral insulin and brain structure in early Alzheimer disease. Neurology 2007;69:1094.

32. Leduc V, Jasmin-Bélanger S, Poirier J. APOE and cholesterol homeostasis in Alzheimer's disease. Trends Mol Med 2010;16:469.

33. Beel AJ, Sakakura M, Barrett PJ, Sanders CR. Direct binding of cholesterol to the amyloid precursor protein: An important interaction in lipid-Alzheimer's disease relationships? Biochim Biophys Acta 2010;1801:975.

34. Martin M, Dotti CG, Ledesma MD. Brain cholesterol in normal and pathological aging. Biochim Biophys Acta 2010;1801:934.

35. Shobab LA, Hsiung GY, Feldman HH. Cholesterol in Alzheimer's disease. Lancet Neurol 2005;4:841.

36. Grösgen S, Grimm MO, Friess P, Hartmann T. Role of amyloid beta in lipid homeostasis. Biochim Biophys Acta 2010;1801:966.

37. Snyder HM, Corriveau RA, Craft $S$, et al. Vascular contributions to cognitive impairment and dementia including Alzheimer's disease. Alzheimers Dement 2015;11:710.

38. Beason-Held LL, Thambisetty M, Deib G, et al. Baseline cardiovascular risk predicts subsequent changes in resting brain function. Stroke 2012;43:1542.

39. Kaffashian S, Dugravot A, Elbaz A, et al. Predicting cognitive decline: a dementia risk score vs. the Framingham vascular risk scores. Neurology 2013;80:1300.

40. Debette $S$, Seshadri $S$, Beiser A, et al. Midlife vascular risk factor exposure accelerates structural brain aging and cognitive decline. Neurology 2011;77:461.

41. Snowdon DA, Greiner LH, Mortimer JA, et al. Brain infarction and the clinical expression of Alzheimer disease. The Nun Study. JAMA 1997;277:813.

42. Bennett DA, Wilson RS, Arvanitakis Z, et al. Selected findings from the Religious Orders Study and Rush Memory and Aging Project. J Alzheimers Dis 2013; 33 Suppl 1:S397.

43. Toledo JB, Arnold SE, Raible K, et al. Contribution of cerebrovascular disease in autopsy confirmed neurodegenerative disease cases in the National Alzheimer's Coordinating Centre. Brain 2013;136:2697.

44. Troncoso JC, Zonderman AB, Resnick SM, et al. Effect of infarcts on dementia in the Baltimore longitudinal study of aging. Ann Neurol 2008;64:168.

45. Riekse RG, Leverenz JB, McCormick W, et al. Effect of vascular lesions on cognition in Alzheimer's disease: a community-based study. J Am Geriatr Soc 2004;52:1442.

46. Kövari $E$, Gold G, Herrmann FR, et al. Cortical microinfarcts and demyelination affect cognition in cases at high risk for dementia. Neurology 2007;68:927.

47. McKhann GM, Knopman DS, Chertkow H, et al. The diagnosis of dementia due to Alzheimer's disease: recommendations from the National Institute on Aging-Alzheimer's Association workgroups on diagnostic guidelines for Alzheimer's disease. Alzheimers Dement 2011;7:263.

48. American Psychiatric Association. Diagnostic and Statistical Manual of Mental Disorders, Fifth Edition (DSM-5), American Psychiatric Association, Arlington, VA 2013.

49. Markowitsch HJ, Staniloiu A. Amnesic disorders. Lancet 2012;380:1429.

50. SCOVILLE WB, MILNER B. Loss of recent memory after bilateral hippocampal lesions. J Neurol Neurosurg Psychiatry 1957;20:11.

51. Zola-Morgan S, Squire LR, Amaral DG. Human amnesia and the medial temporal region: enduring memory impairment following a bilateral lesion limited to field CA1 of the hippocampus. J Neurosci 1986;6:2950.

52. Peters F, Collette F, Degueldre C, et al. The neural correlates of verbal short-term memory in Alzheimer's disease: an fMRI study. Brain 2009;132:1833.

53. Stokholm J, Vogel A, Gade A, Waldemar G. Heterogeneity in executive impairment in patients with very mild Alzheimer's disease. Dement Geriatr Cogn Disord 2006;22:54.
54. Harwood DG, Sultzer DL, Feil D, et al. Frontal lobe hypometabolism and impaired insight in Alzheimer disease. Am J Geriatr Psychiatry 2005;13:934.

55. Barrett AM, Eslinger PJ, Ballentine NH, Heilman KM. Unawareness of cognitive deficit (cognitive anosognosia) in probable $A D$ and control subjects. Neurology 2005;64:693.

56. McDaniel KD, Edland SD, Heyman A. Relationship between level of insight and severity of dementia in Alzheimer disease. CERAD Clinical Investigators Consortium to Establish a Registry for Alzheimer's Disease. Alzheimer Dis Assoc Disord 1995;9:101.

57. Harwood DG, Sultzer DL, Wheatley MV. Impaired insight in Alzheimer disease: association with cognitive deficits, psychiatric symptoms, and behavioral disturbances. Neuropsychiatry Neuropsychol Behav Neurol 2000;13:83.

58. Mizrahi R, Starkstein SE, Jorge R, Robinson RG. Phenomenology and clinical correlates of delusions in Alzheimer disease. Am J Geriatr Psychiatry 2006;14:573.

59. Parakh R, Roy E, Koo E, Black S. Pantomime and imitation of limb gestures in relation to the severity of Alzheimer's disease. Brain Cogn 2004;55:272.

60. Kato $M$, Meguro K, Sato $M$, et al. Ideomotor apraxia in patients with Alzheimer disease: why do they use their body parts as objects? Neuropsychiatry Neuropsychol Behav Neurol 2001;14:45.

61. Giannakopoulos P, Duc M, Gold G, et al. Pathologic correlates of apraxia in Alzheimer disease. Arch Neurol 1998;55:689.

62. Sarazin M, Stern Y, Berr C, et al. Neuropsychological predictors of dependency in patients with Alzheimer disease. Neurology 2005;64:1027.

63. Rahayel S, Frasnelli J, Joubert S. The effect of Alzheimer's disease and Parkinson's disease on olfaction: a metaanalysis. Behav Brain Res 2012;231:60.

64. Sun GH, Raji CA, Maceachern MP, Burke JF. Olfactory identification testing as a predictor of the development of Alzheimer's dementia: a systematic review. Laryngoscope 2012;122:1455.

65. Quarmley M, Moberg PJ, Mechanic-Hamilton D, et al. Odor Identification Screening Improves Diagnostic Classification in Incipient Alzheimer's Disease. J Alzheimers Dis 2017;55:1497.

66. Ju YE, Lucey BP, Holtzman DM. Sleep and Alzheimer disease pathology--a bidirectional relationship. Nat Rev Neurol 2014;10:115.

67. Hauser WA, Morris ML, Heston LL, Anderson VE. Seizures and myoclonus in patients with Alzheimer's disease.Neurology 1986;36:1226.

68. McAreavey MJ, Ballinger BR, Fenton GW. Epileptic seizures in elderly patients with dementia. Epilepsia 1992;33:657.

69. Romanelli MF, Morris JC, Ashkin K, Coben LA. Advanced Alzheimer's disease is a risk factor for late-onset seizures. Arch Neurol 1990;47:847.

70. Zarea A, Charbonnier C, Rovelet-Lecrux A, et al. Seizures in dominantly inherited Alzheimer disease. Neurology 2016;87:912.

71. Vossel KA, Tartaglia MC, Nygaard HB, et al. Epileptic activity in Alzheimer's disease: causes and clinical relevance. Lancet Neurol 2017;16:311.

72. Portet F, Scarmeas N, Cosentino S, et al. Extrapyramidal signs before and after diagnosis of incident Alzheimer disease in a prospective population study. Arch Neurol 2009;66:1120.

73. McKhann G, Drachman D, Folstein M, et al. Clinical diagnosis of Alzheimer's disease: report of the NINCDS-ADRDA Work Group under the auspices of Department of Health and Human Services Task Force on Alzheimer's Disease. Neurology 1984;34:939.

74. Knopman DS, DeKosky ST, Cummings JL, et al. Practice parameter: diagnosis of dementia (an evidence-based review). Report of the Quality Standards Subcommittee of the American Academy of Neurology. Neurology 2001;56:1143.

75. Phung TK, Andersen BB, Høgh P, et al. Validity of dementia diagnoses in the Danish hospital registers. Dement Geriatr Cogn Disord 2007;24:220.

76. Galasko D, Hansen LA, Katzman R, et al. Clinical-neuropathological correlations in Alzheimer's disease and related dementias. Arch Neurol 1994;51:888.

77. Kantarci K, Avula R, Senjem ML, et al. Dementia with Lewy bodies and Alzheimer disease: neurodegenerative patterns characterized by DTI. Neurology 2010;74:1814.

78. Josephs KA, Whitwell JL, Duffy JR, et al. Progressive aphasia secondary to Alzheimer disease vs FTLD pathology. Neurology 2008;70:25.

79. Guidelines for Alzheimer's Disease Management Final Report. Dept of Public Health 2008.

80. Danysz W, Parsons CG. Glycine and N-methyl-D-aspartate receptors: physiological significance and possible therapeutic applications. Pharmacol Rev 1998;50:597. 
81. Kornhuber J, Weller M, Schoppmeyer K, Riederer P. Amantadine and memantine are NMDA receptor antagonists with neuroprotective properties. J Neural Transm Suppl 1994;43:91.

82. Reisberg B, Doody R, Stöffler A, et al. Memantine in moderate-to-severe Alzheimer's disease. N Engl J Med 2003;348:1333.

83. Cummings J, Isaacson R, Schmitt A, Velting D. A practical algorithm for managing Alzheimer's disease: what, when and why? Am Neur Ass 2015;307-323

84. Cummings J, Froelich L, Black SE, et al., Randomized, double-blind, parallelgroup, 48-week study for efficacy and safety of a higher-dose rivastigmine patch (15 vs $10 \mathrm{~cm}^{2}$ ) in Alzheimer's disease. Dement Geriatr Cogn Disord 2012;33:341-353.

85. Farlow MR, Grossberg GT, Sadowsky $\mathrm{CH}$, et al., A 24-week, randomized, controlled trail of rivastigmine patch $13.3 \mathrm{mg} / 24$ versus $4.6 \mathrm{mg} / 24$ in severe Alzheimer's dementia. CNS Neurosci Ther 2013;19:745-752.

86. Rogers SL, Doody RS, and Mohs RC. et al. Donepezil improves cognition and global function in Alzheimer disease: a 15-week, double-blind, placebo-controlled study. Donepezil Study Group. Arch Intern Med 1998;158:1021-1031.

87. Rogers SL, Farlow MR, and Doody RS. et al. A 24-week, double-blind, placebocontrolled trial of donepezil in patients with Alzheimer's disease. Donepezil Study Group. Neurology 1998;50:136-145.

88. Burns A, Rossor M, and Hecker J. et al. The effects of donepezil in Alzheimer's disease: results from a multinational trial. Dement Geriatr Cogn Disord 1999;10:237-244.

89. Farlow M, Scmidt F, and Aarsland D. et al. Comparing clinical profiles in Alzheimer's disease and Pakinson's dementia. Dement Geriatr Cogn Disord Extra 2013;3:218-290.

90. Farlow M, Anand R, and Messina J Jr. et al. A 52-week study of the efficacy of rivastigmine in patients with mild to moderately severe Alzheimer's disease. Eur Neurol 2000;44:236-241.

91. Rosler M, Anand R, and Cicin-Sain A. et al. Efficacy and safety of rivastigmine in patients with Alzheimer's disease: international randomised controlled trial. BMJ 1999;318:633-638.Correction 2001;322:1456.

92. Wilcock GK, Lilienfeld S, and Gaens E. Efficacy and safety of galantamine in patients with mild to moderate Alzheimer's disease: multicentre randomised controlled trial. Galantamine International-1 Study Group. BMJ 2000;321:14451449.Correction 2001;322:405.

93. Tariot PN, Solomon PR, and Morris JC. et al. A 5-month, randomized, placebocontrolled trial of galantamine in AD. Neurology 2000;54:2269-2276.
94. Birks J. Cholinesterase inhibitors for Alzheimer's disease. Cochrane Database Syst Rev. 2006;1:CD005593.

95. Chen R, Chan PT, Chu H, et al. Treatment effects between monotherapy of donepezil versus combination with memantine for Alzheimer disease: A meta-analysis. PLoS One 2017;12:e0183586.

96. Farlow MR, Cummings JL. Effective pharmacologic management of Alzheimer's disease. Am J Med 2007;120:388-397.

97. Chen R, Chan PT, Chu H, et al. Treatment effects between monotherapy of donepezil versus combination with memantine for Alzheimer disease: A meta-analysis. PLoS One 2017;12:e0183586.

98. Tariot PN, Farlow MR, Grossberg GT, et al. Memantine treatment in patients with moderate to severe Alzheimer disease already receiving donepezil: a randomized controlled trial. JAMA 2004;291:317-324.

99. Seltzer B, Zolnouni $P$, Nunez $M$, et al. Efficacy of donepezil in early-stage Alzheimer's disease: a randomised placebo-controlled trial. Arch Neuro 2004;61:185

100. Feldman H, Gauthier S, and Hecker J. et al. A 24-week, randomized, doubleblind study of donepezil in moderate to severe Alzheimer's disease. Neurology 2001;57:613-620.Correction 2001;57:2153.

101. White H. Weight change in Alzheimer's disease. J Nutr Health Aging 1998;2:110

102. Hanson LC, Ersek M, Gilliam R, Carey TS. Oral feeding options for people with dementia: a systematic review. J Am Geriatr Soc 2011;59:463.

103. Woods B, Aguirre $E$, Spector $A E$, Orrell M. Cognitive stimulation to improve cognitive functioning in people with dementia. Cochrane Database Syst Rev 2012:CD005562

104. Forbes D, Forbes SC, Blake CM, et al. Exercise programs for people with dementia. Cochrane Database Syst Rev 2015;:CD006489

105. Teri L, Gibbons LE, McCurry SM, et al. Exercise plus behavioral management in patients with Alzheimer disease: a randomized controlled trial. JAMA 2003;290:2015.

106. Rolland Y, Pillard F, Klapouszczak A, et al. Exercise program for nursing home residents with Alzheimer's disease: a 1-year randomized, controlled trial. J Am Geriatr Soc 2007;55:158.

107. Pitkälä KH, Pöysti MM, Laakkonen ML, et al. Effects of the Finnish Alzheimer disease exercise trial (FINALEX): a randomized controlled trial. JAMA Intern Med 2013;173:894.

108. Graff MJ, Adang EM, Vernooij-Dassen MJ, et al. Community occupational therapy for older patients with dementia and their care givers: cost effectiveness study. BMJ 2008:336:134 